\title{
An analysis of energy efficiency and greenhouse gas emissions from organic soybean cultivation in Brazil
}

\section{Uma análise da eficiência energética e da emissão de gases de efeito estufa no cultivo orgânico de soja no Brasil}

\author{
Roni Fernandes Guareschi ${ }^{1 *}$; Marcio dos Reis Martins ${ }^{1}$; Leonardo Fernandes \\ Sarkis²; Bruno Jose Rodrigues Alves ${ }^{3}$; Claudia Pozzi Jantalia ${ }^{3}$; Robert Michael \\ Boddey $^{3}$; Segundo Urquiaga ${ }^{3}$
}

\begin{abstract}
The assessment of energy efficiency (EE) and greenhouse gas (GHG) emissions can highlight the sustainability of agro-systems and decision-making regarding reduction of production costs and environmental pollution. In this context, the objective of this work was to evaluate the EE and GHG emissions $\left(\mathrm{CO}_{2}, \mathrm{CH}_{4}\right.$ e $\left.\mathrm{N}_{2} \mathrm{O}\right)$ of a soybean crop under organic cultivation in different regions of Brazil in the agricultural year 2014-2015. For this, 19 soybean areas were evaluated. The inputs and outputs of the agricultural operations and / or inputs used were calculated by multiplying the quantity used by their calorific value or energy coefficient at each stage of production. The energy efficiency was obtained by the ratio between the amount of total output energy and the total energy consumption during the production process. In order to estimate GHG emissions, the principles of the life cycle assessment methodology and recommendations of the Intergovernmental Panel on Climate Change (IPCC) were applied. For each 1.0 MJ of energy consumed in the organic production of soybeans, an average of 7.9 $\mathrm{MJ}$ of renewable energy was produced in the form of grains of this crop. The main energy costs of growing these organic crops were with seeds, fuel and with tractors, machines and agricultural implements (TMI). For each $1 \mathrm{~kg}$ of organic grain produced from soybeans, $0.19 \mathrm{~kg}$ of $\mathrm{CO}_{2}$ eq are emitted during their production and delivery cycles in the warehouse. The main sources of $\mathrm{CO}_{2}$ eq emission to the atmosphere were the seeds, fuels and organic fertilizers.
\end{abstract}

Key words: Organic agriculture. Energy. Greenhouse gases. Grain production.

\section{Resumo}

A avaliação da eficiência energética (EE) e emissão de gases de efeito estufa (GEE) podem evidenciar a sustentabilidade dos agrossistemas e a tomada de decisões relativas à redução dos custos de produção e poluição do ambiente. Diante deste contexto, o objetivo deste trabalho foi avaliar a EE e emissões de GEE $\left(\mathrm{CO}_{2}, \mathrm{CH}_{4}\right.$ e $\left.\mathrm{N}_{2} \mathrm{O}\right)$ na cultura da soja sob cultivo orgânico em diferentes regiões brasileiras no ano agrícola de 2014-2015. Para isso, foram avaliadas 19 áreas de soja. As entradas e saídas de energia das operações agrícolas e/ou insumos utilizados foram calculadas pela multiplicação da quantidade utilizada pelo seu poder calorífico ou coeficiente energético em cada etapa de produção. A eficiência energética foi obtida pela razão entre a quantidade de energia total de saída e o consumo total de energia durante

1 Pós-Doutorando, Programa de Pós-Graduação em Ciência do Solo, Universidade Federal Rural do Rio de Janeiro, UFRRJ, Seropédica, RJ, Brasil. E-mail: guareschiecotarelli@hotmail.com; marcio.dos.reis.martins@gmail.com

2 Discente do Curso de Mestrado, Programa de Pós-Graduação em Ciência do Solo, Universidade Federal de Lavras, UFLA, Lavras, MG, Brasil. E-mail: leonardo.sarkis@hotmail.com

3 Pesquisadores, Empresa Brasileira de Pesquisa Agropecuária, EMBRAPAAgrobiologia, CNPAB, Seropédica, RJ, Brasil. E-mail: bruno.alves@embrapa.br; claudia.jantalia@embrapa.br; robert.boddey@embrapa.br; segundo.urquiaga@embrapa.br

* Author for correspondence 
o processo produtivo. Para estimar a emissão de GEE, foram aplicados princípios da metodologia de avaliação do ciclo de vida e recomendações do Painel Intergovernamental sobre Mudanças Climáticas (IPCC). Para cada 1,0 MJ de energia consumida na produção orgânica de soja foram produzidos, em média 7,9 MJ de energia renovável, na forma de grãos desta cultura. Os principais gastos energéticos do cultivo orgânico de soja foram com sementes, combustível e com tratores, máquinas e implementos agrícolas. Para cada $1 \mathrm{~kg}$ de grão de soja produzido organicamente são emitidos $0,19 \mathrm{~kg}$ de $\mathrm{CO}_{2}$ eq considerando desde a produção até o armazenamento. As principais fontes de emissão de GEE em $\mathrm{CO}_{2}$ eq no cultivo de soja orgânica foram as sementes, combustíveis e fertilizantes orgânicos.

Palavras-chave: Agricultura orgânica. Energia. Gases de efeito estufa. Produção de grãos.

\section{Introduction}

Energy efficiency (EE) is the ratio between the total energy produced by a crop ( $\left.\mathrm{MJ} \mathrm{ha}^{-1}\right)$ and the fossil energy consumed in its production $\left(\mathrm{MJ} \mathrm{ha}^{-1}\right)$. Thus, the EE assessment of Brazilian agriculture aims to determine the bottlenecks of the cultivation systems adopted and to identify technologies and energy-saving inputs, especially those of fossil origin, such as fuel, fertilizer, agricultural pesticides, machinery and implements (CAMPOS; CAMPOS, 2004; CUNHA et al., 2015). The EE calculation is a tool for analyzing the economic and environmental sustainability of agricultural production systems.

In Brazilian agriculture, few studies have evaluated EE from organic soybean cultivation (ASSENHEIMER et al., 2009). The potential of organic soybean grows along with the tendency of society to seek healthier living habits, with food being one of its main pillars (INAGAKI et al., 2018). In addition, cultivation on an organic basis can be seen as a factor of added value to the product, thus enabling increased income from rural properties (INAGAKI et al., 2018). This highlights the importance of EE studies in this area, aiming to evaluate the organic production process and the level of sustainability of these systems.

In Brazil, the only study that evaluated EE from the organic soybean crop was Assenheimer et al. (2009). This study, in the state of Paraná, evaluated the EE in the 2003/2004 crop and verified that organic soybean cultivation was efficient in terms of energy return, presenting an EE of 4.40 in the evaluated system. In the case of fossil energy expenditures of agricultural production, it is possible to estimate the contribution of GHG emissions to grain production using life cycle analyses (LCA) (MACEDO et al., 2004, SOARES et al., 2009).

Life Cycle Assessment (LCA) is a technique for assessing the environmental impact associated with the use of natural resources (energy and materials), pollutant emissions and identifying opportunities to improve the system in order to improve the environmental performance of the product during its agricultural and/or industrial phase (QUEIROZ; GARCIA, 2010). In this context, the characteristics of organic agriculture and the need for registration can make LCA an important and feasible activity (PIRES et al., 2002). Thus, in the near future, the certified organic product, like the industrial product with an eco-label, can from an LCA, obtain the organic seal (PIRES et al., 2002). In Brazil, there is still little research with the LCA approach; however, the issue is emerging and has been gaining ground due to society's growing concern about sustainable, socially-just and economically-viable productive practices (CLAUDINO, TALAMINI, 2013).

Considering the above, through the evaluation of energy efficiency and life cycle analysis, one can determine in the cultivation of organic soybean, the factors that aid in environmental degradation and thus propose techniques and/or practices that seek to minimize or suppress these negative factors, thus contributing to the formation of a more sustainable chain of production of these crops.

Therefore, the objective of this study was to evaluate the energy efficiency and life cycle analysis of the soybean crop under organic cultivation in the agricultural year of 2014-2015. 


\section{Materials and Methods}

The research was of the exploratory type and followed the methodological orientations that contemplate multiple case studies, with the use of bibliographical research and interviews with producers. In these multiple case studies, the production units chosen are differentiated (regarding the management) by the adopted production systems, which conceives the non-generalization of their results, but as support and tool for other studies, since they are not considered as "units of sampling "(FERREIRA et al., 2014).

The state of Paraná, stands out for presenting several areas under the cultivation of organic soybean, which the destination of the production is export of grains in natura and / or soya lecithin. Most of these areas are linked in a cooperative system, which provide technical assistance and take care of storage and marketing processes. Therefore, in partnership with the company Gebana Brasil Ltda of Capanema-PR, which works in this cooperative system, management information was collected for EE calculations and GHG emissions from 19 soybean areas under organic cultivation. Data from the harvest year 2014/2015 were analyzed.

The main information collected was: a) Amounts used of labor, fuel, organic fertilizers, seeds, seedlings, agricultural pesticides, among other inputs used from sowing to harvest; b) which agricultural operations are used in crop management, as well as which tractors, machines and / or implements are used for these services; c) grain yield of crops; d) technical indexes, such as time for each agricultural operation and fuel consumption $\left(\mathrm{L}^{-1} \mathrm{~h}^{-1}\right)$.

The information on area size (ha) and yield ( $\mathrm{kg}$ $\mathrm{ha}^{-1}$ ) of soybean areas evaluated in this study (Table 1) is described below.

Table 1. Location, size and average productivity of the areas evaluated under organic cultivation in the state of Paraná.

\begin{tabular}{|c|c|c|c|}
\hline *ID & City/State & Size of area (ha) & Average Productivity $\left(\mathrm{kg} \mathrm{ha}^{-1}\right)$ \\
\hline \multicolumn{4}{|c|}{ - - } \\
\hline 1 & Salto do Lontra-PR & 8.00 & 2700.00 \\
\hline 2 & Salto do Lontra-PR & 11.00 & 2700.00 \\
\hline 3 & Capanema - PR & 3.50 & 2245.71 \\
\hline 4 & Capanema - PR & 1.50 & 2800.00 \\
\hline 5 & Planalto - PR & 8.00 & 2100.00 \\
\hline 6 & São Miguel do Oeste - PR & 5.00 & 2304.00 \\
\hline 7 & Planalto - PR & 8.50 & 2470.59 \\
\hline 8 & Marechal Cândido Rondon - PR & 10.00 & 1920.00 \\
\hline 9 & Palotina - PR & 15.00 & 2604.00 \\
\hline 10 & Capanema - PR & 3.40 & 2541.18 \\
\hline 11 & Palotina - PR & 14.00 & 2738.57 \\
\hline 12 & Planalto - PR & 4.00 & 2490.00 \\
\hline 13 & Planalto - PR & 6.70 & 2059.70 \\
\hline 14 & Santa Helena - PR & 4.50 & 2733.33 \\
\hline 15 & Palotina - PR & 4.00 & 3420.00 \\
\hline 16 & Pérola do Oeste - PR & 6.00 & 2720.00 \\
\hline 17 & Palotina - PR & 4.80 & 1762.50 \\
\hline 18 & Capanema - PR & 4.00 & 2700.00 \\
\hline 19 & Palotina - PR & 9.00 & 2853.33 \\
\hline
\end{tabular}

*Identification numbers of the areas used throughout the text. 'Data supplied by producers, linked to Gebana Brasil. 
By means of visits to the production units (PUs), data were collected on all the inputs (seeds, organic fertilizers, limestone, biofertilizers, fuel, agricultural pesticides, labor) and agricultural practices used and converted into energy units by multiplying the physical product by the respective conversion indexes (energy coefficients), computed in Mega Joules (MJ) (ASSENHEIMER et al., 2009; CAPELLESSO; CAZELLA, 2013).
The conversion of inputs and agricultural practices into energy (Joules) was derived from bibliography, being calculated and adapted to the research conditions, both for inputs (factors necessary for production) and for outputs (grain production) (CAPELLESSO; CAZELLA, 2013). Considering the above, the values of energy coefficients that were used in this study to transform the physical products / inputs into energy are presented in Table 2.

Table 2. Main energy coefficients that were used to determine the energy consumption of the analyzed crops.

\begin{tabular}{cccc}
\hline & \multicolumn{2}{c}{ 1. Direct Energy } & \\
Specifications & Unity & Energy Coefficient (EC) & Bibliographic reference \\
\hline Human workforce & $\mathrm{MJ} \mathrm{h}^{-1}$ man & 7.84 & Boddey et al. (2008) \\
Chicken bed & $\mathrm{MJ} \mathrm{kg}^{-1}$ & 0.126 & Souza et al. (2008) \\
Niorg (Granulated Organic Fertilizer) & $\mathrm{MJ} \mathrm{kg}^{-1}$ & 0.35 & Fadare et al. (2009) \\
Ekosil (ground silicate rock, main & $\mathrm{MJ} \mathrm{kg}^{-1}$ & 1.31 & $*$ \\
source of K and Si) & $\mathrm{MJ} \mathrm{kg}^{-1}$ & 1.67 & Ferraro Junior (1999) \\
Potassium sulphate & $\mathrm{MJ} \mathrm{kg}^{-1}$ & 0.63 & Quadros and Kokuszka (2007) \\
Natural phosphate & $\mathrm{MJ} \mathrm{L}^{-1}$ & 1.64 & Quadros and Kokuszka (2007) \\
Super lean & $\mathrm{MJ} \mathrm{kg}^{-1}$ & 1.31 & Macedo et al. (2004) \\
Lime & $\mathrm{MJ} \mathrm{kg}^{-1}$ & 1.31 & $*$ \\
Gypsum & $\mathrm{MJ} \mathrm{kg}^{-1}$ & 6.32 & Souza et al. (2008) \\
Micronutrients in general & $\mathrm{MJ} \mathrm{L}^{-1}$ & 43.93 & Comitre (1993) \\
Calorific value of diesel oil & $\mathrm{MJ} \mathrm{L}^{-1}$ & 35.94 & Comitre (1993) \\
${ }^{1}$ Calorific value of lubricating oil & $\mathrm{MJ} \mathrm{L}^{-1}$ & 49.22 & Comitre (1993) \\
${ }^{1}$ Grease calorific value & $\mathrm{MJ} \mathrm{kg}^{-1}$ & 31.75 & Pimentel (1980) \\
Seeds of Soy & 5.30 & Sá et al. (2013) \\
Inoculants & $\mathrm{MJ} \mathrm{dose}^{-1}$ & $\mathbf{2 . ~ I n d i r e c t ~ e n e r g y ~}$ & \\
\hline${ }^{2}$ Tractors or machines (Self-propelled) & $\mathrm{MJ} \mathrm{kg}^{-1}$ & 69.83 & Macedônio; Picchioni (1985) \\
Harvesters (Self-propelled) & $\mathrm{MJ} \mathrm{kg}^{-1}$ & 69.87 & Macedônio; Picchioni (1985) \\
Implements (non-self-propelled) & $\mathrm{MJ} \mathrm{kg}^{-1}$ & 57.2 & Macedônio; Picchioni (1985) \\
\hline
\end{tabular}

* Due to lack of data, it was considered the same energy spent for the manufacture and delivery of limestone on the farm (MACEDO et al., 2004). ${ }^{1}$ For the calculation of the consumption of lubricating oil, $1.5 \%$ of the diesel consumption was considered and, for the grease, $33 \%$ of the consumption of lubricant. ${ }^{2}$ An energy value for repairs of tractors, machines and agricultural implements has also been established, which corresponds to $5 \%$ of the total energy used in the manufacture of these.

The calculation of energy depreciation (DE) and indirect energy of tractors, machines and / or agricultural implements were based on BEBER (1989):

$$
\mathrm{DE}=((\mathrm{M}-10 \% * \mathrm{M}) / \mathrm{Vu}) * \mathrm{tu} * \mathrm{CE}
$$

Where: M (tractor mass or agricultural implement in $\mathrm{kg}$ ); $\mathrm{Vu}$ (tractor life or agricultural 
implements in hours); tu (time of use in hours) and CE (energy coefficient of the tractor, machine or agricultural implement analyzed). The mass of the tractors, machines and implements were obtained from the manufacturers' catalogs. The values of useful life were obtained according to data from CONAB (2010).

The energy coefficients used to convert the amount of pesticides used in energy were estimated according to studies in the literature (Table 3).

Table 3. Energy coefficients (EC) used to calculate the energy expenditure with pesticides for pest and disease control in the organic crops evaluated in this study.

\begin{tabular}{|c|c|c|}
\hline Products & $\begin{array}{c}\text { Energy Coefficients } \\
\left(\mathrm{MJ} \mathrm{kg}^{-1} \text { ou L L-1) }\right.\end{array}$ & References \\
\hline Dipel WG (Bacillus thuringiensis) & 257.36 & * \\
\hline Boveril WP (Beauveria bassiana) & 257.36 & $*$ \\
\hline Difere SC (Copper oxychloride) & 363.87 & $*$ \\
\hline Baculovirus anticarsia WP & 257.36 & $*$ \\
\hline Trichodermil SC (Trichoderma harzianum) & 363.87 & $*$ \\
\hline Bordeaux mixture & 0.14 & Souza (2006) \\
\hline Lime sulfur & 1.61 & Quadros and Kokuszka (2007) \\
\hline
\end{tabular}

* Due to the lack of EC values of some products used in organic agriculture, a value was estimated according to Pimentel (1980), which attributes the amount of energy spent with agricultural pesticides according to their formulations in $\mathrm{MJ} \mathrm{kg}^{-1} \mathrm{or} \mathrm{L}^{-1}$ of active ingredient.

As for the calculation of the energy consumption in agricultural operations (distribution of lime, planting, internal transport, application of pesticides, harvesting, etc.), these were obtained through the fuel costs $\left(\mathrm{L} \mathrm{h}^{-1}\right)$ Tractor + implement) or machine used, together with the performance of that set or machine $\left(\right.$ ha $\left.\mathrm{h}^{-1}\right)$. With this data in hand, a fuel expenditure $\left(\mathrm{L} \mathrm{h}^{-1}\right)$ was divided by the yield $\left(\mathrm{ha} \mathrm{h}^{-1}\right)$, obtaining the fuel expenses $\left(\mathrm{L} \mathrm{ha}^{-1}\right)$ and after that a multiplication by the calorific value of the diesel oil (43.93 $\mathrm{MJ} \mathrm{L}^{-1}$ ).

Some of the correction factors discussed in this paragraph were used in the calculations of fuel (diesel) expenditures in grain transport and transhipment operations, water transport and soil preparation. In transport operations (grains and water), the fuel expenditure was divided by the load-carrying capacity per hectare, for example, if a Tractor + water tank set spends $10 \mathrm{~L}$ of diesel to carry $2000 \mathrm{~L}$ of water and the volume per hectare is
$200 \mathrm{~L}$, this means that the $10 \mathrm{~L}$ of diesel consumed in this operation were used for 10 hectares and that in fact the consumption of diesel per hectare in this operation is equal to $1 \mathrm{~L}$. In the soil preparation and soil correction operations, the consumption of diesel and limestone was divided by the number of years of residual effect that the management carried out could provide benefits to the soil.

The relationship of tractors, machines and agricultural implements, as well as the agricultural operations performed in each property are shown in Tables 4 and 5.

The number of hours worked and the total diesel consumption for carrying out all these operations, as well as the quantities of seeds used, organic fertilizers are listed below in Table 6 .

With regard to the energy outputs, to standardize the calculations, the production of soybeans was taken into account at $13 \%$ humidity, adopting, as 
a basis for the conversion of productivity (output) into energy, the value of $16.74 \mathrm{MJ} \mathrm{kg}^{-1}$ (SANTOS et al., 2013). Considering the above, for the total calculation of energy production leaving the agrosystems, it is sufficient to only multiply the grain yield of the crop by its respective energy coefficient, quoted earlier in this paragraph. The residues left by the crop after the harvest were not considered as outputs since they are reincorporated to the system (CAPELLESSO; CAZELLA, 2013).

Table 4. Tractors, machines and agricultural implements used in the agricultural properties evaluated.

\begin{tabular}{|c|c|c|c|}
\hline ID & Traction source & Power (cv) & Implements \\
\hline 1 & Self-propelled Harvester & 175 & - \\
\hline 2 & Tractor & 95 & 28 disc harrow \\
\hline 3 & Tractor & 95 & Solid Dispenser $\left(3 \mathrm{~m}^{-3}\right)$ \\
\hline 4 & Tractor & 95 & Solid Dispenser $\left(3 \mathrm{~m}^{-3}\right)$ \\
\hline 5 & Tractor & 95 & Cultivator/weeder ( 5 stems) \\
\hline 6 & Man & - & Hand weeding \\
\hline 7 & Tractor & 75 & 28 disc harrow \\
\hline 8 & Truck & 150 & Coupled solids distributor \\
\hline 9 & Tractor & 75 & Seed Drill \\
\hline 10 & Tractor & 65 & Sprayer $(600 \mathrm{~L})$ \\
\hline 11 & Tractor & 65 & Cultivator/weeder ( 7 stems) \\
\hline 12 & Man & - & Hand weeding \\
\hline 13 & Tractor & 95 & Seed Drill (5 lines) \\
\hline 14 & Truck & 170 & - \\
\hline 15 & Tractor & 75 & Seed Drill \\
\hline 16 & Tractor & 75 & Seed Drill (7 lines) \\
\hline 17 & Truck & 250 & - \\
\hline 18 & Man & - & Hand weeding \\
\hline 19 & Truck & 170 & - \\
\hline 20 & Man & - & Costal Sprayer \\
\hline 21 & Man & - & Hand weeding \\
\hline 22 & Man & - & Hand weeding \\
\hline 23 & Truck & 170 & - \\
\hline 24 & Man & - & Hand weeding \\
\hline 25 & Tractor & 65 & Cultivator/weeder ( 7 stems) \\
\hline 26 & Truck & 170 & - \\
\hline 27 & Man & - & Hand weeding \\
\hline 28 & Man & - & Hand weeding \\
\hline 29 & Man & - & Hand weeding \\
\hline 30 & Man & - & Hand weeding \\
\hline 31 & Tractor & 95 & Scarifier plow of 5 stems \\
\hline 32 & Man & - & Hand weeding \\
\hline
\end{tabular}

Finally, in order to calculate the energy efficiency $(\mathrm{EE})$, the energy produced $\left(\mathrm{MJ} \mathrm{ha}^{-1}\right)$ was divided by the consumed $(\mathrm{MJ}$ ha-1) in each production unit, while the energy balance will result from the difference between the energy produced (MJ ha-1) and consumed $\left(\mathrm{MJ} \mathrm{ha}^{-1}\right)$ (SANTOS et al., 2013). 
Life cycle analysis (LCA)

One of the ways to estimate the contribution of GHG emissions to grain production can be through the conversion of fossil energy expenditures into equivalent $\mathrm{CO}_{2}$ emissions and with $\mathrm{GHG}$ emission data published in the literature (MACEDO et al., 2004; SOARES et al., 2009).
Thus, using the energy costs of the organic soybean areas mentioned earlier in this module, total GHG emissions expressed in $\mathrm{kg}$ of $\mathrm{CO}_{2}$ equivalent per hectare per year $\left(\mathrm{kg} \mathrm{CO}_{2} \mathrm{eq} \mathrm{ha}^{-1}\right.$ year $\left.{ }^{1}\right)$ were estimated. The factors and/or default GHG emission data used in this estimate were extracted from information published in the literature, as follows:

Table 5. Description of the agricultural operations carried out in the organic soybean properties and the type of machinery used.

\begin{tabular}{|c|c|c|c|c|c|c|c|c|c|c|c|c|}
\hline \multirow{3}{*}{ Areas evaluated } & \multicolumn{12}{|c|}{ * Agricultural operations } \\
\hline & $a^{* *}$ & $\mathrm{~b}$ & $\mathrm{c}$ & $\mathrm{d}$ & $\mathrm{e}$ & $\mathrm{f}$ & $\mathrm{g}$ & $\mathrm{h}$ & $\mathrm{i}$ & $\mathrm{j}$ & $\mathrm{k}$ & 1 \\
\hline & \multicolumn{12}{|c|}{--or } \\
\hline Salto do Lontra-PR & - & $2^{2 \mathrm{X}}$ & 3 & 4 & 9 & 13 & 10 & 5 & 6 & $10^{3 \mathrm{x}}$ & 1 & 14 \\
\hline Salto do Lontra-PR & - & 15 & 8 & 8 & 15 & 16 & 10 & 11 & 12 & $10^{3 \mathrm{x}}$ & 1 & 17 \\
\hline Capanema - PR & - & $2^{2 \mathrm{X}}$ & 3 & - & - & 13 & - & - & 18 & - & 1 & 19 \\
\hline Capanema - PR & - & $2^{2 \mathrm{X}}$ & 3 & - & - & 13 & - & - & 21 & 20 & 1 & 19 \\
\hline Planalto - PR & - & $2^{2 \mathrm{X}}$ & 3 & - & - & 13 & - & - & 22 & $10^{3 \mathrm{x}}$ & 1 & 19 \\
\hline São Miguel do Oeste - PR & - & $2^{2 \mathrm{X}}$ & 3 & - & - & 13 & - & - & 12 & $10^{3 \mathrm{x}}$ & 1 & 23 \\
\hline Planalto - PR & - & $2^{2 \mathrm{X}}$ & 3 & - & - & 13 & - & - & 24 & $10^{3 \mathrm{x}}$ & 1 & 19 \\
\hline Marechal Cândido Rondon - PR & - & 15 & 8 & 8 & - & 15 & - & 25 & 12 & $10^{3 \mathrm{x}}$ & 1 & 17 \\
\hline Palotina - PR & - & $2^{2 x}$ & 3 & - & - & 13 & - & 25 & - & - & 1 & 26 \\
\hline Capanema - PR & - & $2^{2 \mathrm{x}}$ & 3 & - & - & 13 & - & - & 24 & $10^{2 x}$ & 1 & 19 \\
\hline Palotina - PR & - & $2^{2 x}$ & 3 & 4 & - & 13 & - & 25 & 27 & $10^{2 \mathrm{x}}$ & 1 & 26 \\
\hline Planalto - PR & - & $2^{2 \mathrm{X}}$ & 3 & - & - & 13 & - & - & 22 & $10^{2 \mathrm{x}}$ & 1 & 19 \\
\hline Planalto - PR & - & $2^{2 \mathrm{X}}$ & 3 & - & - & 13 & - & - & 28 & $10^{2 \mathrm{x}}$ & 1 & 19 \\
\hline Santa Helena - PR & - & $2^{2 \mathrm{x}}$ & 3 & - & - & 13 & - & - & 24 & $10^{2 \mathrm{x}}$ & 1 & 19 \\
\hline Palotina - PR & - & $2^{2 \mathrm{X}}$ & 3 & - & - & 13 & - & - & 29 & $10^{2 \mathrm{x}}$ & 1 & 26 \\
\hline Pérola do Oeste - PR & - & $2^{2 \mathrm{X}}$ & 3 & - & - & 13 & - & - & 30 & $10^{2 \mathrm{x}}$ & 1 & 19 \\
\hline Palotina - PR & - & $2^{2 \mathrm{X}}$ & 3 & 4 & - & 13 & - & 25 & 29 & $10^{2 \mathrm{x}}$ & 1 & 26 \\
\hline Capanema - PR & 31 & $2^{2 \mathrm{x}}$ & 3 & - & - & 13 & - & - & 22 & - & 1 & 19 \\
\hline Palotina - PR & - & $2^{2 \mathrm{X}}$ & 3 & 4 & - & 13 & - & 25 & 32 & $10^{2 \mathrm{x}}$ & 1 & 26 \\
\hline
\end{tabular}

* Agricultural operations: a) Aração; b) Heavy grading; c) Liming; d) Application of organic fertilizer; e) Planting of green manure or cover plant; f) Sowing; g) Coverage fertilization; h) Mechanical sheathing; (i) manual weeding or use of weed cutter; j) Control of pests and diseases; k) Harvest; 1) Transport to the warehouse. ** Equipment and operating income used and identified by numbers according to Table $4 .{ }^{\mathrm{x}}$ - letter $\mathrm{x}$ followed by an exponent number means the number of times the operation was repeated. *** Some equipment and operating income used in the agricultural operations of some properties were estimated due to lack of data due to the rent or outsourcing of the services practiced. 
Table 6. Quantities of inputs used in the evaluated areas.

\begin{tabular}{|c|c|c|c|c|c|c|c|}
\hline \multirow{2}{*}{ City / State } & $*$ Se & $* \mathbf{F O}$ & *Calc & \multirow{2}{*}{\multicolumn{2}{|c|}{$\begin{array}{c}* \text { Biofert } \\
\left.(\mathrm{kg} \mathrm{ou} \mathrm{L} \mathrm{ha})^{-1}\right)\end{array}$}} & \multirow{2}{*}{$\begin{array}{c}{ }^{*} \text { Comb } \\
\text { L }\end{array}$} & \multirow{2}{*}{$\begin{array}{l}{ }^{*} \mathrm{MH} \\
\text { hours }\end{array}$} \\
\hline & \multicolumn{3}{|c|}{------ kg ha-1 year'-1 ------ } & & & & \\
\hline \multirow{3}{*}{ Salto do Lontra-PR } & \multirow{3}{*}{50} & \multirow{3}{*}{$\begin{array}{l}{ }^{\mathrm{C}} 500.0+ \\
{ }^{\mathrm{G}} 240.0\end{array}$} & \multirow{3}{*}{500.0} & Dipel $^{\circledR}$ & 0.50 & \multirow{3}{*}{64.0} & \multirow{3}{*}{39.5} \\
\hline & & & & Super slim & 3.00 & & \\
\hline & & & & Boveril $^{\circledR}$ & 0.50 & & \\
\hline \multirow{3}{*}{ Salto do Lontra-PR } & \multirow{3}{*}{50} & \multirow{3}{*}{$\begin{array}{c}{ }^{\mathrm{C}} 2000.0+ \\
{ }^{\mathrm{G}} 250.0\end{array}$} & \multirow{3}{*}{312.5} & Dipel $^{\circledR}$ & 0.50 & \multirow{3}{*}{64.7} & \multirow{3}{*}{30.1} \\
\hline & & & & Super slim & 3.00 & & \\
\hline & & & & Boveril $^{\circledR}$ & 0.50 & & \\
\hline Capanema - PR & 57 & $\mathrm{G} 400.00$ & 312.5 & - & - & 37.1 & 26.3 \\
\hline \multirow{2}{*}{ Capanema - PR } & \multirow{2}{*}{53} & \multirow{2}{*}{ G333.00 } & \multirow{2}{*}{312.5} & Ekosil $^{\circledR}$ & 2.00 & \multirow{2}{*}{37.1} & \multirow{2}{*}{88.6} \\
\hline & & & & Boveril $^{\circledR}$ & 1.00 & & \\
\hline \multirow[b]{2}{*}{ Planalto - PR } & \multirow[b]{2}{*}{70} & \multirow[b]{2}{*}{ G156.25 } & & Boveril $^{\circledR}$ & 0.40 & & \\
\hline & & & 312.5 & $\begin{array}{c}\text { Baculovirus } \\
\text { anticarsiae }\end{array}$ & 0.10 & 39.7 & 59.5 \\
\hline & & & & Ekosil $^{\circledR}$ & 2.00 & & \\
\hline & & & & Lime sulfur & 80.00 & & \\
\hline São Miguel do Oeste - PR & 48 & G300.00 & 312.5 & Boveril $^{\circledR}$ & 0.80 & 40.9 & 61.3 \\
\hline & & & & Dipel $^{\circledR}$ & 0.60 & & \\
\hline & & & & Difere $^{\circledR}$ & 1.00 & & \\
\hline & & & & Ekosil $^{\circledR}$ & 0.60 & & \\
\hline Planalto PR & 56 & G235?0 & 3125 & Boveril $^{\circledR}$ & 0.20 & 415 & 573 \\
\hline rtalrato - th & 30 & 253.29 & 312.3 & Dipel $^{\circledR}$ & 0.20 & 41.5 & (5) \\
\hline & & & & Difere $^{\circledR}$ & 0.60 & & \\
\hline & & & & Ekosil $^{\circledR}$ & 1.00 & & \\
\hline & & & & Trichodermil $^{\circledR}$ & 0.10 & & \\
\hline Marechal Cândido & 48 & G300.00 & 312.5 & Baculovirus anticarsiae & 0.01 & 47.7 & 28.5 \\
\hline & & & & Boveril $^{\circledR}$ & 0.10 & & \\
\hline & & & & Dipel $^{\circledR}$ & 1.20 & & \\
\hline Palotina - PR & 57 & ${ }^{\mathrm{G}} 166.00$ & 312.5 & - & - & 44.0 & 6.6 \\
\hline & & & & Ekosil $^{\circledR}$ & 1.50 & & \\
\hline Capanema - PR & 58,8 & G367.6 & 312.5 & Boveril $^{\circledR}$ & 0.60 & 38.8 & 38.6 \\
\hline & & & & Dipel $^{\circledR}$ & 0.60 & & \\
\hline & & & & Dipel $^{\circledR}$ & 0.80 & & \\
\hline Palotina - PR & 57 & C700.0 & 312.5 & Difere $^{\circledR}$ & 0.40 & 52.1 & 20 \\
\hline & & & & Super slim & 205.00 & & \\
\hline Planalto - PR & 50 & G12500 & 3125 & Ekosil $^{\circledR}$ & 2.50 & 379 & 487 \\
\hline & & & & Lime sulfur & 5.00 & & \\
\hline Planalto - PR & 507 & G330 00 & 3125 & Ekosil $^{\circledR}$ & 2.50 & 370 & 807 \\
\hline r tanato- Th & 39,1 & 259.00 & 312.0 & Dipel $^{\circledR}$ & 0.20 & 31.9 & 00.1 \\
\hline
\end{tabular}


continuation

\begin{tabular}{|c|c|c|c|c|c|c|c|}
\hline \multirow{4}{*}{ Santa Helena - PR } & \multirow{4}{*}{44,4} & \multirow{4}{*}{${ }^{\mathrm{G}} 266.66$} & \multirow{4}{*}{312.5} & Ekosil $^{\circledR}$ & 2.50 & \multirow{4}{*}{38.8} & \multirow{4}{*}{50.1} \\
\hline & & & & Boveril $^{\circledR}$ & 0.40 & & \\
\hline & & & & Dipel $^{\circledR}$ & 0.70 & & \\
\hline & & & & Lime sulfur & 44.40 & & \\
\hline \multirow{2}{*}{ Palotina - PR } & \multirow{2}{*}{50} & \multirow{2}{*}{${ }^{\mathrm{G}} 187.70$} & \multirow{2}{*}{312.5} & Ekosil $^{\circledR}$ & 2.50 & \multirow{2}{*}{44.0} & \multirow{2}{*}{56.2} \\
\hline & & & & Dipel $^{\circledR}$ & 0.50 & & \\
\hline \multirow{2}{*}{ Pérola do Oeste - PR } & \multirow{2}{*}{53,3} & \multirow{2}{*}{${ }^{\mathrm{G}} 341.66$} & \multirow{2}{*}{312.5} & Ekosil $^{\circledR}$ & 0.80 & \multirow{2}{*}{38.8} & \multirow{2}{*}{16.5} \\
\hline & & & & Boveril $^{\circledR}$ & 0.20 & & \\
\hline \multirow{3}{*}{ Palotina - PR } & \multirow{3}{*}{58,3} & \multirow{3}{*}{ C4116.00 } & \multirow{3}{*}{312.5} & Ekosil $^{\circledR}$ & 2.50 & \multirow{3}{*}{50.0} & \multirow{3}{*}{21.1} \\
\hline & & & & Dipel $^{\circledR}$ & 0.20 & & \\
\hline & & & & Super slim & 125.00 & & \\
\hline Capanema - PR & 40 & ${ }^{\mathrm{G}} 375.00$ & 312.5 & - & - & 38.6 & 43.5 \\
\hline \multirow{3}{*}{ Palotina - PR } & \multirow{3}{*}{62,2} & \multirow{3}{*}{ c3555.55 } & \multirow{3}{*}{312.5} & Ekosil $^{\circledR}$ & 2.50 & \multirow{3}{*}{52.3} & \multirow{3}{*}{11.8} \\
\hline & & & & Dipel $^{\circledR}$ & 0.60 & & \\
\hline & & & & Super slim & 133.30 & & \\
\hline
\end{tabular}

C - Chicken bed; ${ }^{D s}$ - Waste liquid of pigs; ${ }^{\mathrm{G}}$ - Granulated organomineral fertilizer Gebana, with formulation (N-P-K) 01-07-11, composed of $80 \%$ chicken bed, $10 \%$ potassium sulphate, $8 \%$ natural phosphate and $2 \%$ gypsum. *Se - Seeds; *FO - organic fertilizer; *Calc - Lime; *Biofert - Biofertilizer / agricultural defense; ${ }^{*}$ Comb - fuel; ${ }^{*} \mathrm{MH}$ - human labor.

1) According to Soares et al. (2009) the energy used for the production of herbicides, insecticides and seeds comes from a great diversity of sources, and for this the conversion of $\mathrm{MJ}$ to $\mathrm{CO} 2$ is used assuming the IPCC emission factors for crude oil (2006). According to the IPCC (2006) the combustion of petroleum to produce $1 \mathrm{GJ}$ of energy produces $73.3 \mathrm{~kg} \mathrm{CO}, 0.003 \mathrm{~kg} \mathrm{CH}_{4}$ and $0.00006 \mathrm{~kg}$ of $\mathrm{N}_{2} \mathrm{O}$. This same procedure was also used to convert the energy consumption of organic fertilizers into GHG emissions.

2) The energy embedded in the agricultural machines is counted as if it were the same for the manufacture of steel (energy supplied by mineral coal). According to IPCC (2006) for $1 \mathrm{GJ}$ of energy derived from coal, $94.6 \mathrm{~kg} \mathrm{CO}_{2}, 0.001 \mathrm{~kg} \mathrm{CH}_{4}$ and $0.0015 \mathrm{~kg} \mathrm{~N}_{2} \mathrm{O}$ are emitted.

3) The energy of diesel fuel used as fuel in tractors and agricultural machinery is also converted into GHGs, according to the IPCC (2006). For 1 GJ of energy derived from diesel oil are emitted 74.1 $\mathrm{kg} \mathrm{CO}, 0.003 \mathrm{~kg} \mathrm{CH}_{4}$ and $0.00006 \mathrm{~kg} \mathrm{~N}_{2} \mathrm{O}$.
4) According to the emission factor adopted by the IPCC (2006), the emission caused by liming with dolomitic limestone is $0.13 \mathrm{t} \mathrm{C}-\mathrm{CO}_{2}$ per tonne of lime applied to the soil.

5) The emission of $\mathrm{N}_{2} \mathrm{O}$ from organic fertilizers added to the soil was taken as $1 \%$ of $\mathrm{N}$ in the fertilizer (IPCC, 2006).

A descriptive statistic of all the results was carried out in the 19 soybean areas, obtaining the mean, minimum value, maximum value and standard deviation.

\section{Results and Discussion}

An average energy efficiency (EE) of 7.9 was found in soybean areas evaluated, ie, for each 1.0 MJ of energy consumed, 7.9 MJ of renewable energy was produced as grains of this crop (Figure 1). This average EE of this crop year 2014/2015 was higher than that recorded by Assenheimer et al. (2009) of the 2003/2004 crop, who reported an EE of 4.4 in the cultivation of organic soybean 
in the state of Paraná. This result was due to the management of the organic soybean area evaluated by Assenheimer et al. (2009) which consumed $29 \%$ more energy as fuel and $88 \%$ more energy in organic fertilizer as compared with this study. It can be inferred that this disparity in the consumption of fuel and organic fertilizer occurred due to fact that Assenheimer et al. (2009) evaluated only one area in loco, while the data of our work came from several properties in different regions, thus giving greater representativeness of the management that is carried out in the region.

Regarding the control of weeds in organic soybean cultivation, the energy expenditure is zero, since the management is usually done with manual weeding and cultivator use. However, it is emphasized that the weeding and use of cultivators increases the energy expenditure with human labor and tractors, machines and agricultural implements (TMI). An important observation reported by the farmers during the interviews of this study is that this lower energy expenditure in the control of weeds in the organic soybean crop should not be evaluated as a major advance, considering that this management is the major obstacle to the progress of the organic soybean cultivation in Brazil, since manual labor is expensive, as well as scarce which prevents adoption on a large scale.

Regarding energy expenditure in pest and disease control, it is important to highlight that most of the organic soybean areas evaluated in this study are small farms with a maximum area of 15 hectares (Table 1). Because they are small properties, the suppressive effect of pests and diseases is smaller when compared to a large property. In addition, the lower purchasing power of some farmers prevents them from investing heavily in the application of pesticides for pest and disease control, which results in lower production costs and lower productivity, which end up balancing. However, what was generally observed in this study is that the areas of organic soybean that invested with alternative pesticides to control pests and diseases were the ones that obtained the highest yields and energy yields (Table 1 and Figure 1). 
Figure 1. Total energy consumed (a) and produced (b) in $\mathrm{MJ} \mathrm{ha}^{-1}$ in the agricultural phase and percentage of the main energy expenditure of the organic soybean areas evaluated. Expenses lower than 1\% were discounted, to better prepare it. Human labor (MH), Tractors, agricultural machinery and implements (TMI), Combustible (Comb), Lubricants (L), Grease (G), Energy spent for repairs of tractors, agricultural machinery and implements (ERMN), Seeds (Se), Inoculants (Ino), Limestone (Cal), Organic fertilizers (FO), Biofertilizers and agricultural pesticides for pest and disease control (DAPD).

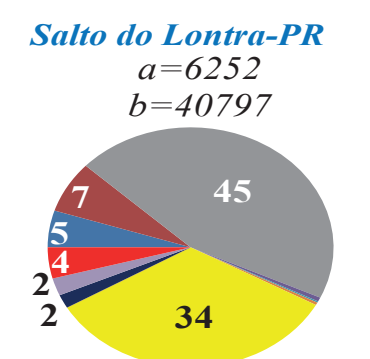

Planalto-PR

$a=5005$

$b=31731$

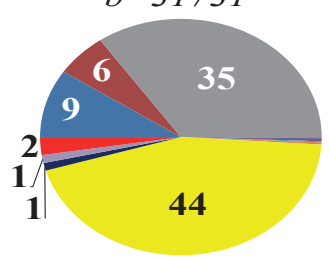

Palotina-PR

$a=4364$

$b=39346$

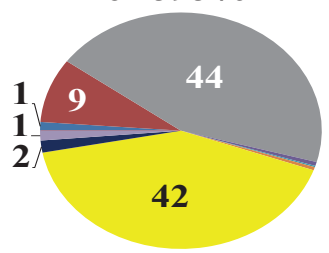

Planalto-PR

$a=4729$

$b=31112$

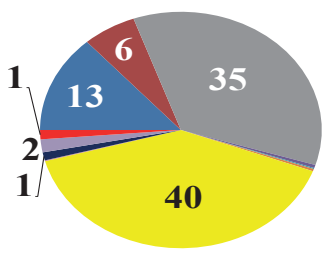

Palotina-PR

$a=5541$

$b=26631$

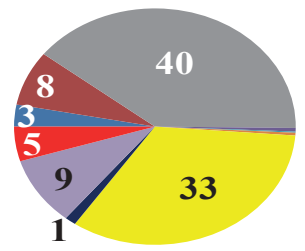

Salto do Lontra-PR

$a=6114$

$b=40797$

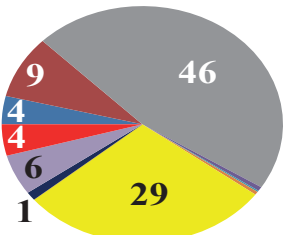

São M. Oeste-PR

$$
a=5267
$$

$b=34813$

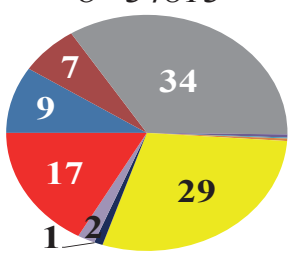

Capanema-PR

$a=4711$

$b=38397$

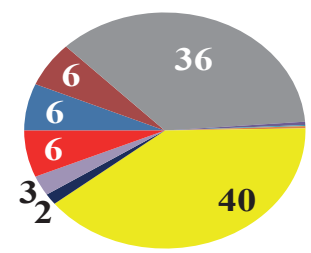

Santa Helena-PR

$a=4356$

$b=41301$

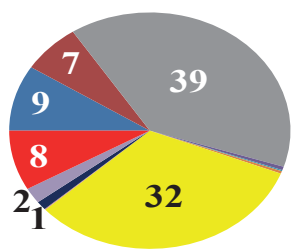

Capanema-PR

$a=3907$

$b=40797$

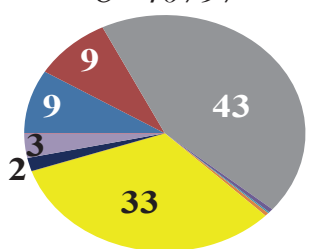

Capanema-PR $a=4117$

$b=33933$

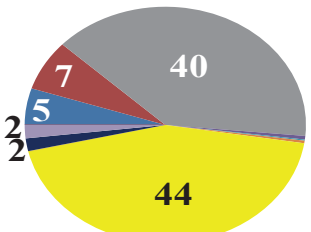

Planalto-PR

$a=4924$

$b=37331$

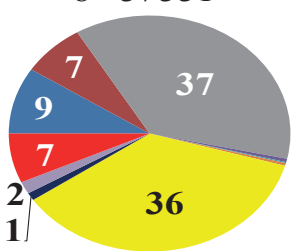

Palotina-PR

$a=5576$

$b=41380$

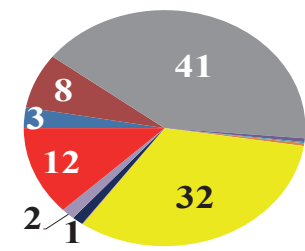

Palotina-PR

$a=4664$

$b=51676$

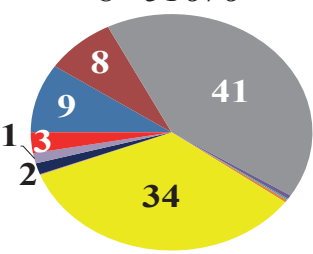

Palotina-PR

$a=5790$

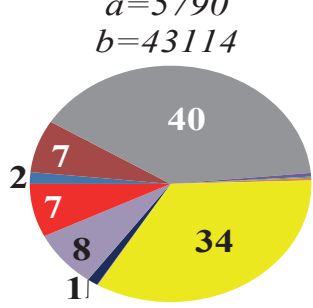

Capanema-PR $a=4779$

$$
b=42308
$$

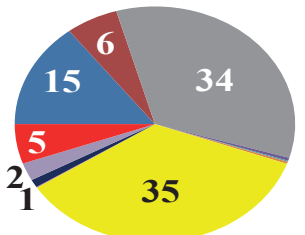

M. C. Rondon-PR $a=4849$

$b=29011$

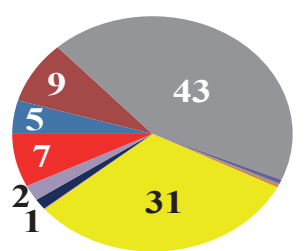

Planalto-PR

$a=4082$

$b=37624$

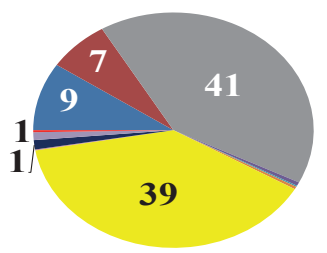

Pérola do Oeste-PR $a=4103$

$b=41099$

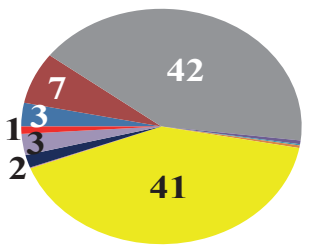

— *MH TMI

Comb Lub

Gra ERMN

$\square$ Se Ino

- Cal $\quad$ FO

- DAPD 
On average, the highest energy expenditure in the evaluated areas of organic soybeans was with fuels (39.9\%), seeds (35.7\%), TMI (7.3\%), human labor $(6.9 \%)$ and biofertilizers and agricultural pesticides for pest and disease control (DAPD) (4.9\%) (Figure 1). Similar results were reported in the work of Assenheimer et al. (2009), where these inputs were also among the main expenditures for the cultivation of organic soybeans in the state of Paraná.

This high proportion of energy consumed with seeds occurs, associated with the high amount of energy per $\mathrm{kg}$ of seeds $\left(34.78 \mathrm{MJ} \mathrm{kg}^{-1}\right)$ due to the high amount of inputs used in seed production areas compared to the production area of grains. This is due to the requirement of a significantly higher seed quality, which depends on strict control of pests, diseases, processing, sorting and packaging (MOURAD; WALTER, 2011; RIQUETTI, 2014). In this way, technologies that improve operational efficiency in the seed production stage would contribute significantly to increase the EE of organic soybean.

The second highest energy expenditure found in the organic and conventional rice areas of the present study was with fuels. One of the ways to try to reduce such energy costs is to increase the efficiency of diesel engines for tractors, harvesters and trucks, with lower fuel consumption per hour worked per hectare. Another way of reducing energy expenditures is by reducing the number of agricultural operations carried out, with the integration of activities.

The third largest energy expenditure recorded in this study in the areas of organic soybean was with TMI, which is a result of the high degree of mechanization in the areas, mainly in the preparation of the soil for sowing. In addition, mechanized cropping practices to reduce or eliminate the use of herbicides (use of brushcutters) and pesticides to control pests and diseases account for the significant contribution of agricultural machinery to total energy expenditure. In this way, the energy consumption with mechanization is increased a little, but it saves a lot in the reduction of expenses with agricultural pesticides.

As for human labor, which assumed the 4th position of higher energy consumption in the cultivation of organic soybean, it can be inferred that this is due mainly to the manual weeding done for weed control in post-emergence. This management requires many hours of service, which in this study varied from 4 to 80 hours ha- ${ }^{-1}$, depending on the size of the area evaluated. Three techniques can be performed in order to reduce these energy costs: 1) planting cover crops in the winter and maintaining a good amount of straw from the previous crop; 2) to achieve a better synchronization between the soil tillage harvests and the sowing time of the soybean, in order to reduce the time between these two treatments, causing the soybean to be sown in a cleaner soil (weed free) and allowing the crop to have more time to grow, develop its biomass area and close the line by suppressing weeds. 3) to use the tractor + cultivator set before the row closure by the soybean crop.

Energy consumption with DAPD can be reduced through integrated pest management and the application of natural pest and disease prevention products. Through the visits made in this study, it can be seen that many areas evaluated in this study are already performing such techniques with good results (Table 1 and 6). In addition to the phytosanitary power, many products present macronutrients, micronutrients and beneficial elements ( $\mathrm{Si}$ ) in their composition, which ensure that soybean plants have a greater phytonutricity in the control of pests and diseases.

Regarding the emissions of greenhouse gases in the areas of organic soybean evaluated, an average emission factor (0.19) was observed, that is, for each $1 \mathrm{~kg}$ of organic soybean produced, $0.19 \mathrm{~kg}$ of $\mathrm{CO}_{2}$ eq (Table 7). There are few or no studies in the literature that have evaluated GHG emissions in the production of organic soybeans in Brazil. 


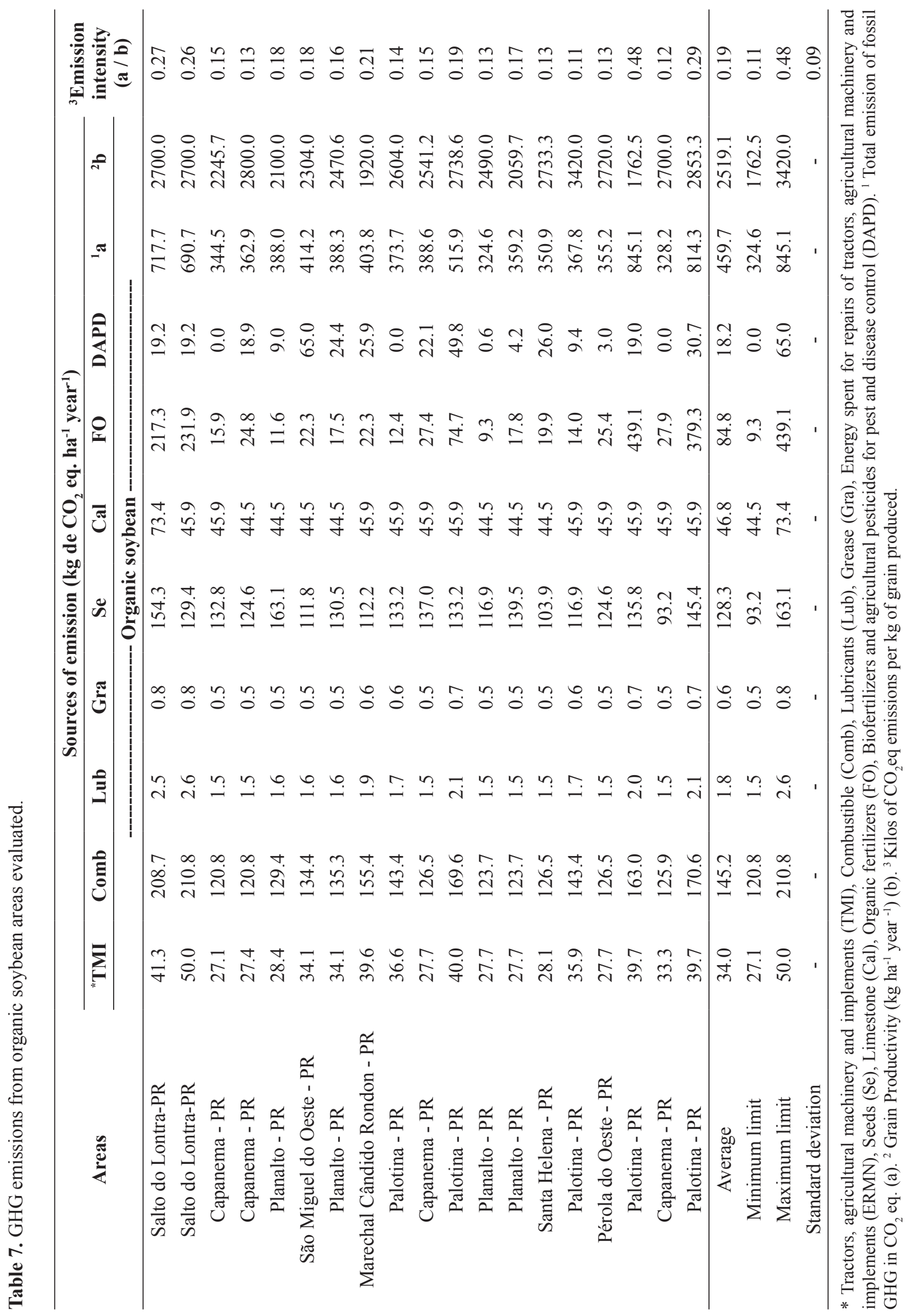


This low average GHG emission factor (0.19) occurs because organic soybean does not use synthetic fertilizers and herbicides, and uses fewer insecticides and fungicides than conventional soybeans.

On average, the five main sources of greenhouse gas emissions from the organic soybean areas evaluated were: 1) fuel $(31.6 \%) ; 2)$ seeds $(27.9 \%)$; $3)$ organic fertilizer (18.4\%); 4) liming (10.2\%); 5) TMI (7.4\%). Together these sources account for $95.5 \%$ of emissions, with $59.5 \%$ being emissions only with fuel and seed consumption (Table 7). These results are a reflection of the higher energy expenditures with these sources (Figure 1). Other works in the literature, but with conventional soybean (non-organic) have also highlighted these sources as the main emitters of GHGs in the cultivation of this crop (CASTANHEIRA; FREIRE, 2013; RAUCCI, 2015).

Considerable contributions from emissions from the use of fuels, seeds, organic fertilizer and IMR are explained by the high energy costs (Figure 1) of these sources in the production stages of organic soybean, and their mitigation can be carried out in a similar ways to those discussed previously.

The organic soybean production systems evaluated in this study proved to be efficient in the use of non-renewable and total energy, even when compared to the conventional production of these crops in the literature, indicating better conditions of sustainability of the organic crop compared to conventional. However, it is noteworthy that the organic production of these crops is still conducted in small areas and by a small number of farmers, in addition to presenting technological deficiencies mainly in the control of weeds, pests and diseases, which would be limiting for large scale production. In view of the above, resolution of the bottlenecks in these areas may further increase the energy efficiency of these crops.

It is important to point out that many organic farming areas initially selected for this study were eliminated because they were not representative of correct organic management. That is, there are still many farmers who consider organic farming as the management of the crop with no fertilizers or pesticides resulting in low productivity. In this way, we emphasize that this mentality must be changed, inserting the concept that organic agriculture of soybean in Brazil already has on offer inputs and technologies which can attain productivities and EE close to or even superior to conventional agriculture. There is, however, a lack of financial incentives and specialized technical assistance for the sector and greater awareness amongst farmers to achieve high productivity organic soybean production.

\section{Conclusions}

For each MJ of energy consumed in organic soybean production, an average of $7.9 \mathrm{MJ}$ of renewable energy was produced in the form of grain of this crop. The main energy costs of the organic cultivation of this crop were with seeds, fuel and with tractors, machines and agricultural implements (TMI).

For each $\mathrm{kg}$ of organic grains produced from soybeans respectively $0.19 \mathrm{~kg}$ of $\mathrm{CO}_{2}$ eq are emitted during their production and delivery cycles in the warehouse. The main sources of $\mathrm{CO} 2 \mathrm{eq}$ emission to the atmosphere being the seeds, fuels and organic fertilizers.

\section{References}

ASSENHEIMER, A.; CAMPOS, A. T.; GONÇALVES JÚNIOR, A. C. Análise energética de sistemas de produção de soja convencional e orgânica. Ambiência, Guarapuava, v. 5, n. 3, p. 443-455, 2009.

BEBER, J. A. C. Eficiência energética e processos de produção em pequenas propriedades rurais. 1989. Dissertação (Mestrado em Extensão Rural) - Universidade Federal de Santa Maria, Santa Maria.

BODDEY, R. M.; SOARES, L. H. B.; ALVES, B. J. R.; URQUIAGA, S. Bio-ethanol production in Brazil. In: PIMENTEL, D. (Ed.). Biofuels, solar and wind as 
renewable energy systems. Dordrecht: Springer, 2008. p. 321-356.

CAMPOS, A. T.; CAMPOS, A. T. Balanços energéticos agropecuários: uma importante ferramenta como indicativo de sustentabilidade de agroecossistemas. Ciência Rural, Santa Maria, v. 34, n. 6, p. 1977-1985, 2004. DOI: $10.1590 / \mathrm{S} 0103-84782004000600050$

CAPELlESSO, A. J.; CAZELLA, A. A. Indicador de sustentabilidade dos agroecossistemas: estudo de caso em áreas de cultivo de milho. Ciência Rural, Santa Maria, v. 43, n. 12, p. 2297-2303, 2013.

CASTANHEIRA, É. G.; FREIRE, F. Greenhouse gas assessment of soybean production: implications of land use change and different cultivation systems. Journal of Cleaner Production, Oxford, v. 54, n. 1, p. 49-60, 2013. DOI: $10.1016 /$ j.jclepro.2013.05.026

ClAUdinO, E. S.; TALAMINI, E. Análise do Ciclo de Vida (ACV) aplicada ao agronegócio - uma revisão de literatura. Revista Brasileira de Engenharia Agrícola e Ambiental, Campina Grande, v. 17, n. 1, p. 77-85, 2013. DOI: $10.1590 / \mathrm{S} 1415-43662013000100011$

COMITRE, V. Avaliação energética e aspectos econômicos da soja na região de Ribeirão Preto, SP. 1993. Dissertação (Mestrado em Engenharia Agrícola/ Planejamento Agropecuário) - Faculdade de Engenharia Agrícola, Universidade Estadual de Campinas, Campinas.

COMPANHIA NACIONAL DE ABASTECIMENTO CONAB. Custos de produção agrícola: a metodologia da Conab. Brasília: Conab, 2010. 60 p.

CUNHA, J. P. B.; CAMPOS, A. T.; MARTINS, F. G. L.; PAULA, V. R.; VOLPATO, C. E. S.; SILVA, F. C. Demanda energética de diferentes manejos de solo no cultivo de milho. Bioscience Journal, Uberlândia, v. 31, n. 3 , p. $808-817,2015$. DOI: $10.14393 / \mathrm{BJ}-$ v31n3a2015-22431

FADARE, D. A.; BAMIRO, O. A.; ONI, A. O. Energy analysis for production of powdered and pelletised organic fertilizer in nigeria. Journal of Engineering and Applied Sciences, Cairo, v. 4, n. 4, p. 75-82, 2009.

FERRARo JUNIOR, L. A. Proposição de método de avaliação de sistemas de produção e de sustentabilidade. 1999. Dissertação (Mestrado em Fitotecnia) Universidade de São Paulo, Piracicaba.

FERREIRA, F. F.; NEUMANN, P. S.; HOFFMANN, R. Análise da matriz energética e econômica das culturas de arroz, soja e trigo em sistemas de produção tecnificados no Rio Grande do Sul. Ciência Rural, Santa Maria, v. 44 , n. 2 , p. $380-385,2014$. DOI: $10.1590 / \mathrm{S} 0103-$ 84782013005000157
INAGAKI, M. N.; JUNQUEIRA, C. P.; BELLON, P. P. Desafios da produção de soja orgânica como determinante à implantação de seu cultivo para fins comercias na região oeste do Paraná. Revista Gestão e Sustentabilidade Ambiental, Florianópolis, v. 7, n. 1, p. 682-699, 2018. DOI: 10.19177/rgsa.v7e12018682-699

INTERGOVERNMENTAL PANEL ON CLIMATE CHANGE - IPCC. Guidlines for national greenhouse gas inventories. Genebra: IPCC, 2006. Disponível: http:// www.ipccnggi.iges.or.jp/public/2006gl. Acesso em: 2 mar. 2015.

MACEDO, I. C.; LEAL, M. R. L. V.; SILVA, J. E. A. R. Balanço das emissões de gases do efeito estufa na produção e no uso do etanol no Brasil. São Paulo: Secretaria do Meio Ambiente, 2004. 34 p.

MACEDÔNIO, A. C.; PICCHIONI, S. A. Metodologia para o cálculo do consumo de energia fóssil no processo de produção agropecuária. Curitiba: Secretaria de Estado da Agricultura, 1985. 95 p.

MOURAD, A. L.; WALTER, A. The energy balance of soybean biodiesel in Brazil: a case study. Biofuels, Biofuels, Bioproducts and Biorefining, Hoboken, v. 5, n. 2, p. 185-197, 2011. DOI: 10.1002/bbb.278

PIMENTEL, D. Handbook of energy utilization in agriculture. Boca Raton: CRC Press, 1980. 475 p.

PIRES, A. C.; RABELO, R. R.; XAVIER, J. H. V. Uso potencial da análise do ciclo de vida (ACV) associada aos conceitos da produção orgânica aplicados à agricultura familiar. Cadernos de Ciência \& Tecnologia, Brasília, v. 19, n. 2, p. 149-178, 2002.

QUADROS, K. R.; KOKUSZKA, R. Balanço energético em sistemas de produção convencional e agroecologico de feijão, na região de Rebouças-PR. Revista Brasileira de Agroecologia, Cruz Alta, v. 2, n. 1, p. 50-54, 2007.

QUEIROZ, G. C.; GARCIA, E. E. C. Reciclagem de sacolas plásticas de polietileno em termos de inventário de ciclo de vida. Revista Polimeros, São Carlos, v. 20, n. 1, p. 401-406, 2010. DOI: 10.1590/S010414282011005000003

RAUCCI, G. S. Greenhouse gas assessment of Brazilian soybean production and postharvest nitrous oxide emissions from crop residues decomposition. 2015. Dissertação (Mestrado em Química na Agricultura e Ambiente) - Universidade de São Paulo, Piracicaba.

RIQUETTI, N. B. Produtividade, eficiência energética e econômica em semeadura cruzada de soja. 2014. Tese (Doutorado) - Universidade Estadual Paulista Júlio de Mesquita Filho, Botucatu. 
SÁ, J. M.; URQUIAGA, S.; JANTALIA, C. P. SOARES, L. H. B.; ALVES, B. J. R.; BODDEY, R. M.; MARCHÃO, R. L.; VILELA, L. Balanço energético da produção de grãos, carne e biocombustíveis em sistemas especializados e mistos. Pesquisa Agropecuária Brasileira, Brasília, v. 48, n. 10, p. 1323-1331, 2013. DOI: 10.1590/S0100-204X2013001000003

SANTOS, H. P.; FONTANELI, R. S.; SPERA, S. T.; DREON, G. Conversão e balanço energético de sistemas de produção com integração lavoura-pecuária, sob plantio direto. Revista Brasileira de Ciências Agrárias, Recife, v. 8, n. 1, p. 1-7, 2013. DOI: 10.5039/agraria. v8i1a1392
SOARES, L. H. B.; ALVES, B. J. R.; BODDEY, R. M.; URQUIAGA, S. Mitigação das emissões de gases efeito estufa pelo uso de etanol da cana-de-açúcar produzido no Brasil. Seropédica: EMBRAPA Agrobiologia, 2009. 14 p. (Circular técnica, 27).

SOUZA, J. L. Balanço energético em cultivos orgânicos de hortaliças. 2006. Tese (Doutorado em Fitotecnia) Universidade Federal de Viçosa, Viçosa, MG.

SOUZA J. L.; CASALI, V. W. D.; SANTOS, R. H. S.; CECON, P. R. Balanço e análise da sustentabilidade energética na produção orgânica de hortaliças. Horticultura Brasileira, Brasília, v. 26, n. 4, p. 433-440, 2008. DOI: $10.1590 / \mathrm{S} 0102-05362008000400003$ 